\title{
NEGÓCIO JURÍDICO \\ UMA RELEITURA À LUZ DOS \\ PRINCÍPIOS CONSTITUCIONAIS
}

Marcos Jorge Catalan*

SUMARRIO: 1.O Mito das Codificaçôes. 2. O Intervencionismo Estatal. 3 , A Constitucionalizacão do Direito Privado. 3.1 A tutela dos hipossuficientes. 4. Quebrando Paradigmas: Una Nova Visão Principiológica. 5. A Exegese do Negócio Jurídico à Luz da Norma Constitucional. 5.1 A função social do contrato. 6. Conclusão. 7. Bibliografia.

SUMMARY: 1. The Myth of the Codifications. 2. State Interventionism. 3. The Constitucionalizaça of the Private law. 3.1 The guardianship of the hipossuficientes. 4. Breaking Paradigms: A New Principiológica Vision. 5. The Exegese of the Legal transaction to the Light of the Constitutional rules. 5.1 The social function of the contract. 6. Conclusion. 7. Bibliography.

SUMARIO; 1 . El mito de las codificaciones. 2. Estado Intervencionista. 3 , La constitucionalización del derecho privado. 3.1 La tutela de los hipossuficientes. 4. Romper Paradigmas: Una Nueva Vision Principiologica. 5. La Exegese de la transacción legal a la luz de las reglas constitucionales. 5.1 La función social del contrato. 6. Conclusión. 7. Bibliografra.

RESUMO: O negócio juridico não pode mais ser interpretado sob a égide da liberdade absoluta e ilimitada. Algumas normas de natureza cogente hão de ser observadas, vátias delas oniutudas do proprio texto constitucional, que deve servir como cercania aos principios da autonomia da vontade e da pacta sunt servanda.

ABSTRACT: The legal transaction cannot be interpreted under the protection of absolute and limitless freedom. Some nature law cogens have being observed, and several of them are originated from constitutional text, that must serve as limits to the autonomy principles of the will and pacta sunt servanda.

"Mestrando en Direito Negocial na Chiversidade Estadual de Londrina. Professor de Direito Civil da Universidade Paranaense, campus Paranavaí. 
RESUMEN: La transacción legal no puede más ser interpretada debajo la tutela de la labertad absoluta e ilimitada. Algunas normas cogentes naturales deben ser observadas, vatias de ellas son denivadas del texto constitucional, que debe senvir como cercanía a los principios de la autonomía del la voluntad y del pacta sunt servanda.

PALAVRAS-CHAVE: Negócio Juridico. Princípios constitucionais.

KEY-WORDS: Legal Transaction. Constitutional principles.

PALABRAS-LLAVES: La transacción legal. Principios constitucionales.

\section{O Mito das Codificações}

A gênese do direito constitucional se deu há algum tempo, dessarte, em terras pátrias, até poucas décadas atrás, ao mesmo não era dada a devida importância, ao menos nas relações jurídicas existentes no vasto campo do direito privado, vez que o apogeu do processo de codificação do direito civil, e a suposta completude dos códigos dos séculos XIX e XX, serviu como anteparo hábil a barrar a luz e o calor provenientes da estrela mais importante do ordenamento jurídico, em torno da qual gravitam todas as demais normas e micro-sistemas legislativos.

Sob o dogma da auto-suficiência do direito civil codificado, os civilistas desprezavam o conteúdo das disposições constitucionais, conduta que acentuou a clássica dicotomia existente entre direito público e privado, de sorte que, na seara deste último, apenas seria admitida a intervenção das normas constitucionais, de modo transverso, quando autorizado pelo artigo $4^{\text {a }}$ da Lei de Introdução ao Código Civil. ${ }^{1}$

É preciso lembrar que a autonomia da vontade é uma idéia desenvolvida nos séculos XVIII e XIX, por estudiosos que precederam a Revolução Francesa e carregava em seu ventre o dogma da liberdade formal, principal garantia para o desenvolvimento da sociedade burguesa em ascensão ${ }^{2}$, bem como sua irmã siamesa, a pacta sunt servanda.

E tal postura libertária, muito embora não seja a mais adequada, é plenamente justificável ante o contexto histórico em que se deu o processo de codificação do direito civil, em meio a queda do absolutismo do Estado e o fortalecimento da burguesia, época em que imperava, de modo praticamente absoluto, a idéia de 
igualdade formal, enquanto discurso que garantiria a defesa dos interesses do povo (melhor seria dizer a propriedade da classe burguesa emergente) contra a ingerência do Poder Público.

[...] já tivemos a oportunidade de ressaltar o equívoco de tal concepção, ainda hoje difusamente adotada, que acaba por relegar a norma constitucional, situada no vértice do sistema, a elemento de integração subsidiário, aplicável apenas na ausência de norma ordinária específica e após terem sido frustradas as tentativas pelo interprete, de fazer uso de analogia e de regra consuetudinária. Trata-se, em uma palavra, de verdadeira subversão hermenêutica. $O$ entendimento ora criticado mostra-se, no entanto, bastante coerente com a lógica do individualismo oitocentista, sendo indiscutível o papel predominante que o Código Civil desempenhava como referência normativa exclusiva no âmbito das relações de direito privado.

$\mathrm{Na}$ mesma esteira de raciocínio, a idéia de negócio jurídico, nascida há pouco mais de 200 anos, em um período de reafirmação de liberdades individuais e que coincidiu com a gênese do desenvolvimento da sociedade industrial, aparentemente oferecia uma solução coerente à ciência jurídica, na medida em que permitia o estudo unitário dos fenômenos sob uma roupagem una e dotada da força tão necessária ao direito. ${ }^{4}$

Há de ressaltar-se que, esta mesma autonomia privada, que eclodiu por ocasisao da Revolução Francesa, nutriu-se de razões de ordem filosófica, política e econômica, enquanto fruto do jusnaturalismo que via o direito como essência pré-existente ao homem; da luta contra o feudalismo que visava garantias à burguesia em ascensão em detrimento do poder dos monarcas absolutistas da época; e por fim, do mercantilismo ante o estágio embrionário das bases capitalistas. ${ }^{5}$

Em verdade, observado o direito como instrumento de dominação das massas pela classe dominante ${ }^{6}$, a autonomia da vontade surge como pano de fundo, legitimando os anseios da classe burguesa, que buscava afastar o intervencionismo estatal, exercer de modo absoluto o direito de propriedade, e justificar a exploração da base operária. ${ }^{7}$

\footnotetext{
${ }^{3}$ TEPEDINO, Gustavo. O código civil, os chamados microssistemas e a Constituição: premissas para uma reforma leyisiativa. In: Problemas de direito civil constitucional. Coord. Gustavo Tepedino. Rio de Janeiro: Renovar, 2001, p. 03.

" FACHIN, Luiz Edson. Novo conceito de ato e negócio juridico: consequêneias práticas, Cutitiba: EDUCA, SCENTIA et LABOR, 1988, p. 09.

5 AMARAL Francisco. Direito civil: introduça Rio de Janeiro: Renowar, 2002, p. 363-365.

"COELHO, Luiz Fenando. Teoria critica do direito. Belo Horizonte: Del Rey, 2003, passim.

'BORGES Nelson. A teoria da imprevisäo no direito civil e no processo crvil Sáo Paulo: Malbeiros, 2002 , p. 135.
} 
O legislador pátrio, em 1916, por ocasião da promulgação do Código Civil seguiu a mesma linha dos diplomas oitocentistas, inspirado no Code Napoleon, criando um modelo negocial centrado em bases individualistas, autorizado em razão da igualdade formal, e que tem como efeito mais importante a criação de lei entre os particulares com a mesma força de qualquer norma válida dentro do ordenamento $^{8}$, sob inspiração da pacta sunt servanda.

Durante muito tempo, o negócio jurídico foi interpretado tendo como bússola a idéia de impossibilidade de descumprimento do ajustado, sendo essencial a prevalência da vontade manifestada, salvo na hipótese da existência de patologias, no momento da formação, ou das clássicas excludentes de responsabilidade, quando da execução.

Ocorre que a organização da economia nos dias atuais, é bastante diversa da que imperava nos séculos passados, e o direito não deixou de observar tal evolução, o que por conseqüência, fez com que as legislações inspiradas no individualismo e na força obrigatória dos contratos tornassem-se manifestamente inadequadas, ou ao menos, devem ser vistas como deficientes para enfrentar os problemas da atualidade, fato que levou à transformação da idéia de negócio jurídico, não $\mathrm{cm}$ seu aspecto material, mas sim em sua concepção filosófica e fenomenológica. ${ }^{10}$

$O$ fortalecimento do Estado, a seu turno, também colaborou para o declínio do mito das codificações, posto que de mãos dadas com ele, caminhou o direito público, centro gravitacional do sistema jurídico, cujo astro de maior importância é certamente a Constituição. ${ }^{11}$

Neste condão pode afirmar-se que o que o Estado deseja, é um direito privado em vez de um direito dos particulares. E a intervenção estatal justifica-se quando se concebe que a autonomia privada deve ser restringida na medida em seja impedida de ocupar "territórios socialmente sensiveis." 12

\footnotetext{
"O art 1134 do Código Civil francês veio consagrar como principio liberal a autonomia privada ao dispor: as convençôes legalmente formadas impôem-se como lé àqueles que a celebraram.

- DONNINI, Rogerio Ferraz. A Constituição Federal e a concepção social do contrato. In: Temas atuais de diréto civil na Constituição Federal. Organizaçăo: Rui Geraldo Camargo Viana e Rosa Maria de Andrade Nery. Säo Paulo: Revista dos Tribunais, 2000 , p. 70.

10 ESPINOLA, Eduardo. Dos contratos nominados no direito civil brasileiro. Atualização: Ricardo Rodrigues Gama. Campinas: Bookseller, 2002, p. 08-09.

"ALBUQUERQUE, Ronaldo Gatti de. Constituição de codificaçăo: a dinâmica atual do binổmio. In: A reconstruçâ do direito privado. Org. Judith Martins Costa. São Paulo: RT, 2002, p. 75.

12 LORENZETTI, Ricardo Luis. Fundamentos do direito privado. Trad. Vera Maria Jacob de Fradera. Säo Paulo: RT, 1998 , p. 540.
} 


\section{O Intervencionismo Estatal}

Observou-se no início do século passado, que a ordem jurídica que prometia a igualdade política não era apta a ensejar a igualdade econômica, e isto se deu, entre outros fatores, em razão da expansão do capitalismo, que trouxe consigo a industrialização, a criação de incontáveis empresas e a conseqüente massificação da produção em detrimento dos contratantes. Verificada tal desproporção na suposta igualdade entre as partes, o Estado entendeu por bem intervir nos negócios jurídicos, restringindo os limites da atuação da vontade das partes, e ao mesmo tempo, permitindo a revisão de cláusulas ou a resilição dos contratos, por meio da intervenção do Poder Judiciário, fenômeno que se denominou dirigismo contratual ${ }^{13}$, e que tem por escopo proteger o economicamente mais débil do jugo dos poderosos, minimizando as diferenças existentes no plano concreto. ${ }^{14}$

A autonomia privada, que ate então consistia num poder quase absoluto conferido às partes pelo sistema, de dar-se um ordenamento, a partir da intervenção estatal, passa a ser delimitada por novas cercanias. E os anteparos da autonomia privada são a ordem pública, que se define como o corpo de princípios e regras jurídicas que regem os interesses essenciais dos sujeitos de direito e aquelas que se inserem na seara do direito privado e regulam as relações econômicas; e os bons costumes, caracterizandose estes na lista de regras morais que transita no seio social. ${ }^{15}$

Outrossim, para que aceite sem restrições a imposição de barragens que não poderão ser transpostas, sob pena de inundar o sistema e afogar a sociedade, há de destacar-se que, o limite imposto à autonomia da vontade, deve ser enxergado de outro ângulo, que não o de mera restrição à liberdade, mas sim como prinćpio dotado de vida própria, sob a denominação de heteronomia da vontade.

O fato é que a heteronomia da vontade, ao ser tratada, de modo subsidiário e derivado, como simples limite da autonomia da vontade, sem que the fosse atribuído o devido status de princípio jurídico de mesma importância, com pouca divulgação e sempre criticado, caiu no ostracismo jurídico e filosófico, apesar de sua enorme importância para as

\footnotetext{
13 PEREIRA, Caio Mário da Silva. Instituicões de direito civil. vol. III. Rio de Janeiro: Forense, 2001, p. 12.

it BRAVO, Maria Celina; SOUZA, Máro Jotge Uchoa. O contrato do terceiro milêtio. Artigo capturado na internet: http//www1.jus.com.br/doutrina/texto.asp?id=2365, em 15.06 .2002 .

${ }^{15}$ AMARAL. Francisco. Direito civil: introdução. Rio de Janeiro: Renovar, 2002, p. 337. Afrmat o autor que as normas cogentes são as que se impöe de modo absoluto, não sendo possivel a sua derrogação pela vontade das partes. Idem. Ibidem. p. 73. Cf: AZEVEDO. Alvaro Villaça. Teoria geral dos contratos típicose atípicos. São Paulo: Attas, 2002, p. 25. Discorre o autor que o Estado, muitas vezes interfere na ordem privada, retirando dos individuos a possibilidade de exercício pleno da liberdade contratual buscando fazer que o direito de uma das partes não seja diminúdo pelo da outra, evitando assim a colisão de direitos, lembrando ainda que as normas de ordem publica não podem ser alteradas pela vontade das partes.
} 
sociedades atuais [...]. Preferimos mapear a ocorrência do princípio da heteronomia da vontade na legislação brasileira, dividindo-a em dois grandes grupos: I - na Constituição Federal; e II - na legislação civil infraconstitucional, codificada ou extravagante, e na jurisprudência. ${ }^{16}$

Outrossim, a releitura do direito privado, parte da premissa de que a necessidade de observância a princípios éticos e morais é essencial ao pleno desenvolvimento da sociedade, e pauta-se por respeitar a liberdade humana ao impor o respeito ao próximo. ${ }^{17}$

As limitações impostas pelo ordenamento têm por escopo humanizar as manifestações de vontade, respeitada a individualidade e a condição social de cada uma das partes, socializando as relações negociais em busca do bem comum ${ }^{18}$, numa visão holística do homem.

Num ordenamento que admita, sem limitaçôes, a liberdade contratual não há justiça ou retidão contratual imanente, assente em critérios objetivos. Importa criar e garantir os pressupostos da formação dos contratos, num quadro de real e efetiva autodeterminação recíproca. Impõe-se corrigir ou impedir os desenvolvimentos absolutos da liberdade contratual, assegurando uma situação de real liberdade e igualdade dos contraentes, e as exigências da justiça social. ${ }^{19}$

No Brasil, tal processo se dá com grande intensidade a partir da década de trinta do século passado, seguindo o mesmo caminho do direito europeu. Surgem leis extravagantes, visando disciplinar os novos institutos ou dar outro enfoque a normas já existentes, alterando seu conteúdo. A partir dos anos 60 , observa-se uma explosão de leis esparsas, gravitando em seu próprio sistema; o que faz com o que o Código Civil deixe de ser o centro das atenções ${ }^{20}$, momento denominado de fase da descodificaçăo do direito privado.

\footnotetext{
LOURENCO, José. O dirigismo contratual, a publicização do direito privado pela intervenção do estado e a heteronomia da vontade como princípio do contrato. In: O direito civil no século XXI. Coord. Maria Helena Diniz e Roberto Senise Lisboa. São Panlo: Saraiva, 2003, p. 349-351.

${ }_{17}$ RIPERT, Georges. A regra moral nas obrigaçōes civis. Trad. Osório de Oliveira. Campinas: Bookseller, 2002 , p. 26.

: GAGLIANO, Pablo Stolze; PAMPLONA FLLO, Rodolfo. Nowo curso de direito civil: parte geral. São Paulo: Saraiva, 2002, p. 316.

19 MOTA PINTO. Carlos Alberto da. Teoria geral do direito civil. Coimbrat Coimbra Editora, 1992, p. 98. Cf: FACHIN, Luiz Edson. Teoria crítica do direito civil, Rio de Janeiro: Renovar, 2000, pp. 207/208: No 'código', o contrato estava confinado ao dogma da vontade, que passou por toda a elastecida aplicaça da cláusula rebus e hoje se submete a algumas interrogaçoes sobre a amplitude da possibilidade da intervença judicial, na autonomia dos contratos e da ética contratual.

27 TEPEDINO, Gustavo. O código civil, os chamados microssistemas e a Constituição: premissas para uma reforma legislativa. In Problemas de diretto civil constitucional. Coord. Gustavo Tepedino. Rio de Janeiro: Renovar, 2001, p. 0405.
} 
As leis do inquilinato ${ }^{2 i}$, espalhadas pelos vários Estados hodiernos, por exemplo, destinadas à proteção dos locatários mediante a fixação de preço dos alugueres e assegurando sua permanência nos imóveis locados, consistem em um exemplo evidente dos novos limites impostos. A obediência aos princípios da boa-fé $e^{22}$ e da função social ${ }^{23}$ também é imperiosa, sendo que esta última norma de conduta, também atua como cercania da autonomia privada, dando prevalência ao interesse coletivo em detrimento do individual, numa demonstração hialina da preocupação do legislador com o bem estar da sociedade.

Boa-fé, equidade e razoabilidade são as pedras angulares da nova teoria geral do contrato e procuram atenuar os abusos potenciais de uma liberdade sem limites. Os conceitos filosóficos econômicos da teoria clássica dos contratos foram, portanto, atenuados e transformados. A nova realidade exige que tenhamos em conta a relevante função econômica e social desempenhada pelo contrato e as condiçôes particulares de cada uma das partes. ${ }^{24}$

As limitações da lei da usura também servem como exemplo, pois "o que se tem em vista é estabelecer um limite para a exploração feneratícia, adotando o Estado a tarifação do interesse, como elementar da remuneração para o capital mutuado, em base que foi reputada conveniente ao interesse público." ${ }^{.25}$

Afere-se assim, que o direito civil sofreu interferências das idéias fecundadas ao longo do século XX. O espírito de justiça coletiva se sobrepõe ao ideal individualista de outrora, levando ao abandono da tradicional postura dogmática jus-positivista. A crescente ingerência do Estado, especialmente sob inspiração marxista, põe em cheque a concepção liberal da economia. ${ }^{26}$

Como se denota, o individualismo exacerbado da fase clássica do negócio jurídico é abandonado em prol de uma nova ordem composta de inúmeras normas de natureza cogente. Mas o que teria motivado esta nova postura adotada pelo legislador?

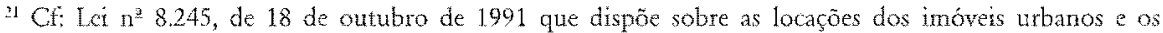
procedimentos a elas pertinentes.

22 Lei 10406/02. Art 422. Os contratantes são obrigados a guardar, assim na conclisão do contrato, como em sua execução, os principios de probidade e boa-fe.

"Lei 10.406/02. Art. 421. A liberdade de contratar seráa exercida em razão e nos limites da funçăo social do contrato. 2HOUREIRO, Luiz Guilherme. Teoria geral dos contratos no novo código crvil São Paulo: Método, 2002, p. 41. 3 PEREIRA. Caio Mário da Silva. Lesão nos contratos. Rio de Janeiro: Forense, 2001, p. 161.

3t LOURENCO, José. O dirigismo contratual, a publicização do direito privado pela intervenção do estado e a heteronomia da vontade cono princípio do contrato. In: O direito civil no século XXI. Coord. Maria Helena Diniz e Roberto Senise Lisboa. Săo Paulo: Saratva, 2003, p. 336.
} 
Não se pode negar que a sociedade atual esta inserida em um contexto bastante diverso do que imperava há pouco mais de 50 anos. A massificação dos contratos fere a crença na igualdade formal, que até então imperava. A despersonalização dos contratos distancia os sujeitos, e por conseqüência, a confiança nascida na liberdade contratual, encontra-se definhada. Outrossim, nunca se contratou tanto como neste início de século, inserindo o negócio jurídico em um plano privilegiado. ${ }^{27}$

Ocorre que na maioria destes contratos, em razão de inexistir a fase prénegocial, a liberdade contratual resta bastante limitada, posto que o principal fator que motiva as partes é a premente necessidade de sobrevivência (dentro de padrões mínimos de qualidade de vida), seja ao adentrar em um hipermercado para a aquisição de mercadorias básicas à subsistência; quando se adentra em um ônibus para chegar em tempo ao trabalho; por ocasião da adesão aos serviços básicos de água, energia elétrica e telefonia; quando se contrata o seguro obrigatório, ou ainda, quando se busca evitar danos à vida ou ao bem estar físico e psicológico, contratando um plano de saúde.

$\mathrm{Na}$ maioria destes negócios jurídicos, não se observa a fase das tratativas, e por conseqüência, o que se vê no plano concreto, é que o pólo mais forte da relação jurídica impõe sua vontade ao mais fraco quando the apresenta a minuta ou os termos do contrato, como se este fosse uma norma emanada do Poder Público que deva ser necessariamente cumprida.

Indaga-se agora, tendo como exemplos os contratos de adesão e os obrigatórios, em que momento se afere o tão aplaudido princípio da autonomia da vontade? Limitar-se-ia apenas a liberdade, de optar ou não, pelo serviço ou pelo produto, quando se sabe que a vida atual impõe aos membros do tecido social uma série de necessidades básicas.

Daí a necessária intervenção estatal, na medida em que não se pode mais olhar os sujeitos apenas à luz da relação jurídica abstrata, distante da realidade, mas sim observá-la enquanto concreção que se reproduz como coelhos, tendo como eixo o homem comum, o cidadão simples, e por consequência, criando normas que assegurem sua felicidade no mundo real, buscando a justiça contratual, que traz em seu bojo, entre outros, a boa fé objetiva, a revisão contratual, o princípio da lesão nos contratos, a invalidade das cláusulas abusivas e a regra interpretatio contra stipulatorem. 


\section{A Constitucionalização do Direito Privado}

A constitucionalização do direito privado deve ser entendida como a inserção no texto constitucional de matérias que dizem respeito aos interesses particulares; enquanto publicização é o regramento de condutas previstas em normas infraconstitucionais por meio de regras de natureza cogente. ${ }^{28}$

Assim, rompendo com a tradição clássica, o texto constitucional alterou o modelo histórico de negócio jurídico baseado nos interesses individuais, na medida em que impöe o estudo deste instituto, tendo como Cruzeiro do Sul a Lei Maior, posto que positiva padrões de conduta a serem observados pelos sujeitos de cada relação jurídica negocial prestes a nascer; processo que se denomina de constitucionalização do direito civil..$^{29}$

Saliente-se que na medida em que surgem os direitos sociais de segunda geração, status positivos, estes se incorporam também às normas infraconstitucionai ${ }^{30}$, posto que se faz necessária a obediência à hierarquia e a coerência do sistema. Situadas no cume da pirâmide normativa, as regras constitucionais, impõem suas diretrizes a todas as demais normas do sistema.

A denominada constitucionalização do direito civil, neste início de terceiro milênio, tem como um de suas premissas, lutar contra o histórico mecanismo de legitimação da exclusão social denominado negócio jurídico ${ }^{31}$, defendido sob o argumento de ser o mais importante instrumento apto a promover o desenvolvimento econômico da sociedade.

Um dos marcos mais importantes do texto constitucional, no que pertine à atividade negocial, encontra-se normografado no artigo $170 .^{32}$ Deste modo, é certo que nenhuma atividade negocial poderá ser exercida quando em conflito com os ditames da justiça social. A livre iniciativa, deve pautar-se por promover a felicidade das pessoas, servindo como instrumento para a redução de desigualdades sociais. ${ }^{33}$

A Constituição incorpora novos valores principiológicos, que deixam de

\footnotetext{
20 LOBO, Paulo Luiz Netto. Artigo capturado na internet: Constitucionalização do direto civil. www.mundojuridicoadv.br, em 05.07 .2003 .

27 DONNINI, Rogério Ferraz. A Constituçảo Federal e a concepçâo social do contrato. In: Temas atuais de direito civil na Constituição Federal. Organização: Rui Geraldo Camargo Viana e Rosa Maria de Andrade Nery. São Paulo: Revista dos Tribunais, 2000, p. 76

31) LISBOA, Roberto Senise. Contratos difusos e coletivos: consumidor, meio ambiente, trabalho, locação, autor. São Paulo: RT, 2000 , p. 71.

it FACHIN, Luiz Edson. Teoria critica do dircito civil. Rio de Janeiro: Renovar, 2000, p. 99.

${ }^{32}$ Ast. 170. A ordem economica, fundada na valorizaçäo do trabalho humano e na livre inciativa, tem por fim assegurar a todos existencia digna, conforme os ditames da justiça social, observados os seguintes princípios: 33 DONNINI, Rogério Ferraz. A Constituição Federal e a concepção social do contrato. In: Temas atuais de direito civil na Constituição Federal. Organizaçäo: Rui Geraldo Camargo Vana e Rosa Maria de Andrade Nery. Săo Paulo: Revista dos Tribunais, 2000, p. 76.
} 
ser aplicados apenas supletivamente e passam a servir de proteína para os negócios jurídicos que nascem diutumamente, ligando-se a ele umbilicalmente, dando-lhes a necessária força para que possam nascer e alcançar sua maturidade.

Os preceitos constitucionais converteram-se em normas de conformação do sistema, e em sendo superiores hierarquicamente, condicionam a exegese das normas infraconstitucionais, entre elas, as normas de direito privado. ${ }^{34}$ Pode afirmar-se até mesmo, que inexiste liberdade contratual, quando esta ofende a igualdade substancial entre os sujeitos da relação jurídica, posto que "os princípios e as regras constitucionais se aplicam direta e imediatamente nas relações interprivadas." 35

O novo método de interpretação civil-constitucional busca um amplo favorecimento do ser humano nas relações jurídicas, e no que pertine aos negócios jurídicos, mitiga o peso da vontade em prol de outros valores tutelados pela Lei Maior; posto que a autonomia da vontade, muito embora possa navegar tranqüilamente nos rios do direito privado clássico, época em que imperava o dogma da liberdade formal; certamente afundará no oceano do Direito Social do welfare state, já que quase que inexiste, por exemplo, no âmbito dos contratos de adesão e dos contratos obrigatórios, ambos frutos da massificação negocial. ${ }^{36}$

Acerca da constitucionalização do direito privado, há de destacar-se ainda que o texto constitucional inovou ao inserir em seu bojo a previsão de proteção do consumidor, pólo pais fraco da relação jurídica negocial. ${ }^{37}$

\subsection{A tutela dos hipossuficientes}

A proteção aos hipossuficientes pode ser considerado um raciocínio que chocaria alguns juristas renomados do período clássico do contrato, caso thes fosse possivel retornar à vida. Dar às partes tratamento diferenciado, seria, certamente, uma inconcebível ofensa ao princípio da igualdade formal. Inserir pesos na balança da deusa Thêmis, com o intuito de equilibrar a relação jurídica, por certo ofenderia o teor do negócio jurídico concebido à luz do direito civil dos tempos das grandes codificações.

\footnotetext{
* LOBO, Paulo Luiz Netto. Direito contratual e constituiçäo. Artigo capturado na internet: http:// www 1. jus.com.br/doutrina/taxto aspid $=563$, em 13.05 .2002 .

3 FACHIN, Luiz Edson. Teotia chtica do direito civil. Rio de Janeiro: Renovat, 2000, p. 33

36 NALN, Paulo. Do contrato: conceito pós-moderno en busca de sua formulaçấo na perspectiva civit constitucional. Curitiba: Juruá, 2001, p. 91.

"Vide CF/89, Art. 5\%, XXXII- O Estado promoverá, na forma da lei, a defesa do consumidor. 
Ocorre que hodiernamente, em diversas situações levadas a juízo, é exatamente esta a postura que se espera dos membros do Poder Judiciário. Em um país em que quase $1 / 3$ de sua população vive à margem da linha da miséria, como entender que a igualdade formal seja equivalente a equivalência material.

Mais que um mero apego à liberdade contratual, prevalecem razões de ordem moral e econômica, com poder para modificação de cláusulas prejudiciais a um dos contratantes, que está situado num plano de inferioridade perante o outro. Uma infinidade de obrigações assumidas por um dos celebrantes, cuja renda salarial e poder aquisitivo não comportam tal soma de encargos, pode levar a admitir-se a culpa contratual do contratante mais forte, por não aferir corretamente a capacidade econômica do inadimplente. [...] Tornase evidente a distribuição de ônus pelo descumprimento do contrato. Reduzem-se, pois, os efeitos do inadimplemento. Invertem-se, ou, pelo menos, equiparam-se as posições quanto às obrigações assumidas. ${ }^{38}$

Neste condão, inspirado no princípio da isonomia, o legislador deu em $1990^{39}$, o primeiro passo na busca de uma sociedade mais justa e fraterna, mediante padrões de justiça distributiva.

Ao se posicionar em defesa do pólo mais frágil na relação jurídica negocial, limitando o poder dos mais fortes ao declarar a nulidade de cláusulas ofensivas a preceitos éticos e isonômicos, o Estado faz do contrato um instrumento de Justiça Social. ${ }^{40}$

O princípio da isonomia, com a autoridade emanada da Constituição, garante aos sujeitos de direito, idêntico tratamento, sem discriminação. Dessarte, tal prescrição legal não passaria de mera abstração se o Estado não cuidasse de editar normas buscando sua eficácia na selva de pedra, não obstante a auto-aplicabilidade das normas constitucionais. ${ }^{41}$

\footnotetext{
38 RIZZARDO, Arnaldo. Contratos. Rio de Janeiro: Forense, 2001, p. 24.

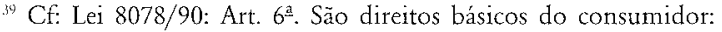

V - a modificação das cláusulas contratuais que estabeleçam prestaçôes desproporcionais ou sua revisão em razão de fatos supervenientes que as tornem excessivamente onerosas;

VIII - a facilitação da defesa de seus direitos, inclusive com a inversão do ônus da prova, a seu favor, no processo civil, quando, a critério do Juiz, for verossímil a alegação ou quando for ele hipossuficiente, segundo as regras ordinárias de experiências.

40 BRAVO, Maria Celina; SOUZA, Mário Jorge Uchoa. O contrato do terceiro milènio. Artigo capturado na internet: http://www1.jus.com.br/doutrina/texto.asp?id=2365, em 15.06.2002.

${ }^{+1}$ NOVAIS, Alinne Arquette Leite. A teoria contratual e o código de defesa do consumidor. São Paulo: RT, 2001, p. 85.
} 
E tal caminho se traça em razão das pessoas jurídicas disporem, no mais das vezes, de amplos mecanismos de defesa, enquanto o consumidor, seja de modo individual ou coletivamente, é a parte mais débil na relação jurídica, sendo vulnerável na medida em que desconhece os processos de comercialização dos bens e ainda sujeita-se aos crônicos problemas do judiciário, entre eles a morosidade e os altos custos de um processo. ${ }^{42}$

\section{Quebrando Paradigmas: Uma Nova Visão Principiológica}

O negócio jurídico, inspirado no individualismo francês, foi informado por muito tempo, entre outros, pelos princípios da autonomia da vontade, da pacta sunt servanda, e da relatividade dos efeitos dos contratos, que em síntese, nas relações entre os particulares, outorgavam-lhes o poder de auto-regrarem, quase que ilimitadamente, suas relações jurídicas, por conseqüência obrigando-se, e eventualmente aos seus sucessores, descartadas, nesta última hipótese, as obrigações intuito personae. Ocorre que, como visto, a autonomia privada está assentada na suposta igualdade entre as partes, o que colide com a realidade social, posto que a ululante diferença econômica e intelectual existente entre os sujeitos na grande maioria das relaçôes jurídicas, atenta contra a idéia de solidariedade social. ${ }^{43}$

Outrossim, em que pese a manutenção de tais princípios, há de destacar-se que aos mesmos não pode ser dada tanta atenção como outrora, posto que são frutos de um comportamento egoísta não mais aceito pela sociedade moderna, sendo que a autonomia privada foi brindada com novas cercanias, consagrando-se o personalismo ético que insere o homem no centro da ordem privada. ${ }^{44}$

A moderna teoria geral do direito civil, hodiernamente semeada em solo adubado por princípios constitucionais, deve sim continuar sendo irrigada pela autonomia da vontade e pela livre iniciativa, "sem que se deixem de observar os princípios de direito e de moral que devem pautar o solidarismo social." 45 Deste modo, como novo limite, influenciado pelos regimes de esquerda ${ }^{46} \mathrm{e}$ imposto às partes que pretendem aventurar-se na

\footnotetext{
42. FLOMENo, José Geraldo Brito. Código de defesa do consumidor comentado pelos autores do anteprojeto. Ada Pellegrini Grinover [et al.]. Rio de Janeiro: Forense Universitária, 1997, p. 27

4. SANTOS, Antônio Jevá. Função social, lesão e onerosidade excessiva nos contratos. Săo Paulo: Metodo, 2003, p. 43.

* AMARAL Francisco dos Santos. Autonomia privada. In: Comentários sobre o projeto de código civil brasileiro. Brasilia: CJF, 2002, p.80.

45 GAGLIANO, Pablo Stolze; PAMPLONA FLLHO, Rodolfo. Novo curso de direito civil: parte geral. Säo Paulo: Samava, 2002 , p. 317.

Wh RZZARDO, Annaldo. Contratos. Rio de Janeiro: Forense, 2001, p. 09 
elaboração de normas individuais de conduta, encontra-se o princípio da sociabilidade, previsto expressamente nos artigos $421^{47}$; e $1.228, \S \S 1^{148}$ e $4^{1249}$ do novel diploma privado.

Muito se comenta também, acerca da função social da empresa ${ }^{50}$, raciocínio que leva a entender como superada a simples idéia de risco econômico como essência da atividade empresarial, pois muitos dependem do seu sucesso para garantir sua sobrevivência e de seus entes queridos.

O novo Código Civil funda-se na premissa de que os valores coletivos deverão prevalecer, quando em colisão com os individuais, sem que com isso, o valor da pessoa humana seja desprezado. Tem ainda como pilar que lhe dá sustentação, um maior apego à realidade contemporânea, propondo um enfoque diverso no estudo e aplicação do direito civil clássico. ${ }^{51}$

A premissa invocada é fruto da transição do Estado Liberal para o Estado Social (welfare state), que trouxe consigo algumas preocupações com uma significativa parcela da sociedade até então marginalizada. No plano constitucional, a melhor descrição de solidariedade busca a redução das desigualdades..$^{52}$

Deste modo, o novo comportamento estatal passa a regular a atividade negocial, delimitando o poder econômico, já que aqui é que se insere o processo de circulação de bens e riquezas. Assim, se é certo que as constituições promulgadas sob o império dos regimes sociais preocuparam-se em assegurar a livre iniciativa, também é correto que se preocupam com os efeitos destas relaçóes jurídicas no seio da sociedade. ${ }^{53}$

Do raciocínio desenvolvido, depreende-se que, não poderá ser visto como lícito um negócio jurídico firmado com fins anti-sociais, em razão da ululante ofensa à norma constitucional ${ }^{54}$, como por exemplo, o pactuado entre os

\footnotetext{
7 Art. 421. A liberdade de contratar será exercida em razão e nos limites da função social do contrato. " $\$ 1^{3} \mathrm{O}$ direito de propriedade deve ser exercico em consonância com as suas finalidades econômicas e sociais e de modo que sejam preservados, de conformidade com o estabelecido em lei especial, a flora, a fauna, as belezas naturais, o equilibrio ecológico e o patrimonio histórico e artístico, bem como evitada a poluiçăo do ar e das águas.

19 \$2 O proprietário também pode ser privado da coisa se o imóvel reivindicado consistir em area extensa, na posse ininterrupta e de boafé, por mais de cinco anos, de considerável número de pessoas, e estas nela houverem [sic] realizado, em conjunto ou separadamente, obras e serviços considerados pelo juiz de interesse social e económico relevanté.

5n Cf: Lei 6404/76: Art. 154. O administrador deve exercer as atribuiçöes que a lei e o estatuto the conferem para lograr os fins e no interesse da companhia, satisfeitas as exigencias do bem público e da função social da empresa. Veja também: TRT 6을. AP 2362/98. 3ํㅡ. T. Relo Juíza Eneida Melo. DOEPE 23.03.1999. "SUCESSÃO TRABALHISTA. VÍNCULO LABORAL SUBORDINADO. A sucessão, no direito do Traba" tho, näo se confunde com a do Direito Civil. Os arts. 10 e 448 da CLT o demonstram. Tal ocorre, entre outros fatores, pela função social da empresa, que não é mais vista como plena propriedade de um dono." "REALE, Miguel. As diretrizes fundamentas do projeto do código civil. In: Comentários sobre o projeto de código civil brasileiro. Brasilia: CJF, 2002, p.15.

52 NALIN Paulo. Do contrato: conceito pós-moderno em busca de sua formulação na perspectiva civilconstitucional. Curitiba: Juruá, 2001 , p. 179.

"LOBO, Paulo Luiz Netto. Direito contratual e constituição. Artigo capturado na internet: http// www 1.jus.com.br/doutrina/texto,aspid $=563$, em 13.05.2002.

54 BETII, Emillo. Teoria geral dos negocios jurídicos. Coimbra: Ed. Coimbra, 1969, tomo I, p. 224.
} 
produtores de alimentos geneticamente modificados, em razão dos riscos potenciais causados pelo comércio dos mesmos para toda a sociedade, sujeita a não impossíveis mutaçōes genéticas transferidas às futuras gerações por conta do consumo dos transgênicos.

Claro reflexo da eticidade como princípio informador do negócio jurídico encontra-se no teor dos artigos 317 , e 884 a 886 do novo Código Civil, enquanto instrumentos que inibem o enriquecimento sem causa, bem como a possibilidade de redução do quantum indenizatório, no contrato de transporte (Art. 738) quando a vítima concorra para o evento danoso ${ }^{55}$ ou ainda o dever imposto ao juiz de reduzir o valor fixado a título de cláusula penal (Art. 413) quando a obrigação seja cumprida em parte.

Ressalte-se também, que o respeito à dignidade humana ${ }^{56}$ adquiriu especial relevo nos últimos anos, multiplicando-se as conferências, declarações e pactos em que se reconhecem os direitos fundamentais da pessoa $^{57}$ e a mesma estrada foi trilhada pelo texto constitucional pátrio. $\mathrm{Na}$ trilha da assertiva acima, questiona-se se também não restaria ofendido o princípio da dignidade da pessoa humana, por conta do comércio de bens (= organismos geneticamente modificados ou seres clonados) que não são fruto da evolução natural, mas da vontade homem em brincar de Deus. ${ }^{58}$

O sistema aberto do novel codex permite, por sua vez, um maior distanciamento do rigor normativo, conferindo aos juízes, não só o poder necessário para suprir lacunas, como também, criar o direito em consonância com o princípio da eticidade. ${ }^{59}$

Aliás, a necessidade de observância da função social do contrato, expressamente inserida no texto do atual Código Civil ${ }^{60}$, sob as vestes de cláusula geral, justifica a preocupação do legislador em proteger a coletividade, concedendo ao magistrado, efetivo poder jurigeno ${ }^{6 \downarrow}$ quando da aplicação da norma ao caso concreto, dando ao sistema a necessária operabilidade.

Este terceiro corolário há de ser destacado. O princípio da operabilidade

\footnotetext{
39 MARTINS COSTA, Judith; BRANCO, Gerson Luiz Carlos. Diretrizes teóricas do novo código civil brasileiro. Säo Paulo: Saraiva, 2002, p. 140.

$\$$ Of Constituça Federal. Att. 1*. A República Federativa do Brasil, ... tem como fundamentos:

III - a dignidade da pessoa humana;

PEREZ, Jesus Gonzales. La dignidade de la persona. Cidade Desconhecida: Civitas S.A, 1968 , p. 30.

FERREIRA Tussata Suzi Assis Borges Nasser. Bioctica e biodireito: a superação da lei. Palestra proferida no VI Semana Juridica de Paranayaí. Paranayá, 27 de agosto de 2001.

$\because$ REALE, Miguel. As dirctrizes fundamentais do projeto do codigo civil. In: Comentários sobre o proteto de código civil brasileiro. Brasilia: CIF, 2002, p.16-17.

Cf: Artigo 421. A liberdade de contratar serí exercida em razăo e nos limites da função social do contrato.

"CF NERY JUNIOR, Nclson. O novo Codigo Givil e sua influência no Direito Brasteiro e no Processo Civil. Palestra proferida no II Congresso Paranaense de Processo Civil. Curitiba, 09-11 de maio de 2002.
} 
consiste na criação de normas que possam ser aplicadas concretamente em beneficio da coletividade, e não apenas, tal qual um quadro de Salvador Dali, distorcer o concreto em surreal, servindo apenas para discursos políticos e discussões acadêmicas. ${ }^{62}$

O princípio da operabilidade também possui sua parcela de influência no atual modelo de sistema adotado pela codificação de direito privado, para que a atividade social possa desenvolver-se, alterando seu conteúdo por meio da "estrutura hermenêutica", ao dotar o julgador de poderes de criar normas para cada situação concreta que se-lhe apresente.

Não se pode deixar de lado outro baluarte, que certamente não é nenhum infante dentro do ordenamento, mas a cuja importância, apenas há algum tempo fora dado o devido destaque. A boa fe $\mathrm{f}^{64}$, consiste num princípio importantíssimo, que tem por objetivo direcionar os destinos das relações jurídicas em geral.

Em terras tupiniquins, embora de uso consagrado pela doutrina e jurisprudência, a matéria não se encontrou positivada na codificação civil há pouco enterrada, dessarte sua aplicação explícita se dá hoje pela positivação do tema no artigo 422 do novo Código Civil, que em forma de cláusula geral ${ }^{65}$ veio corrigir a omissão legislativa anterior, inserindo o referido princípio há algum tempo já utilizado na seara privada ${ }^{66}$.

Não se pode olvidar que tais princípios não mais podem ser desprezados quando se realiza o processo de exegese de qualquer negócio jurídico, sob pena de ofensa a todo o sistema jurídico e não apenas ao direito das partes.

\section{A Exegese do Negócio Jurídico à Luz da Norma Constitucional}

De certo, como resta claro, não há como se conceber, que o direito civil seja isolado dos demais ramos do direito. As diversas áreas do direito, tal qual os ecossistemas, são entes vivos e dinâmicos que interagem sem a presença de zonas fronteiriças concretas e definidas.

\footnotetext{
42 KUMPEL, Vitor Frederico. Direito civil: apontamentos sobre o novo código civil: Lei $10.406 / 02$. Módulo complementar desenvolvido no Congresso Nacional de Direito Civil. Curitiba, 2003, p. 20.

". REALE, Miguel. As diretrizes fundamentais do projeto do código civil. In: Comentários sobre o projeto de código civil brasileiro. Brasilia: CJF, 2002, p.19.

a Nos termos do $\$ 242$, do $\mathrm{BGB}$ : $O$ devedor é obrigado a realizar a prestação do modo como o exige a boa-fé levando em conta os usos do tráfico.

65 Enunciaçăo abstrata, sem consequència expesşa ná Lei, cuja vivificação será motivada pelo magistra* do que dispóe de efetivo poder jurigeno.

w COSTA, Judith Martins. Boate no direito privado. São Paulo: RT, 2000, p. 382. Leciona a autora que a boa-fé objetiva á desempenha um papel fundamental, porque é o caminho pelo qual se permite a construçäo de uma noça substancialista do direto, atuando cono um modelo bábil à elaboraçăo de un sistema aberto, que evolui e se perfaz dia-a-dia.
} 
Deste modo, o estudo e a aplicação do direito privado, apropria-se de outras fontes, que não apenas os dispositivos presentes em um código ou no corpo das leis esparsas.

Neste mar de fontes, não se pode esquecer que se encontra a Constituição da República ${ }^{67}$, como porto mais importante para a plena realização do Direito, especialmente porque "não se interpreta o direito em tiras, aos pedaços."

O vértice de todo o ordenamento jurídico é constituido pelo direito constitucional. Seguramente que se encontrarão, portanto, na Constituição Política principios determinantes do conteúdo do direito civil português [...] Importa, ainda, reter o reconhecimento do direito à iniciativa privada, a garantia da propriedade privada e da sua transmissão em vida ou por morte [...]. .9 $^{9}$

No Brasil, a influência da Constituição Federal de 1988 no direito privado foi "avassaladora" , fazendo com que esta passasse definitivamente a ser o centro gravitacional do sistema jurídico, enterrando de vez a idéia do direito civil como macro-sistema autônomo e independente. A este respeito, merece lembrança o princípio da interpretação conforme a Constituição, considerando-se que a recente evolução do direito constitucional assistiu à aparição deste preceito interpretativo, ${ }^{11}$ buscando aferirse se a vontade do legislador será ou não cumprida, caso conduza a uma interpretação viciada de ilegitimidade constitucional. ${ }^{22}$

Decantada a discussão acerca da importância do texto maior para a eficácia normativa em um sistema jurídico, há de destacar-se que a Constituição interfere na vida dos negócios jurídicos de duas maneiras, seja quando deve necessariamente lastrear a exegese daquele, ou ainda quando inspira o legislador a readequar normas que estão perdendo o brilho e o perfume das suas pétalas, agindo como um jardineiro que retira as folhas mortas e afasta as ervas daninhas que põe em risco a harmonia do seu jardim. Ambos os enfoques são de relevante importância.

Neste condão, não se pode esquecer que a atividade interpretativa é a

67 CORDEIRO, Antonio Menezes. Tratado de direito civil português: parte geral. Almedina: Lisboa, 2000 , tomo I, p. 111

"SRAU, Eros Roberto. Ensaio e discurso sobre a interpretação / aplicação do direito. São Paulo: Malheiros, 2002, p. 34.

"MOTA PINTO. Carlos Aberto da Teoria geral do dircito civil Coimbra: Coimbra Editora, 1992, p. 53-54.

7" FRADERA, Véra Maria Jacob de. O direito dos contratos no século XXI: a construção e uma noção metanacional de contrato decorrente da globalização, da integração regional e sob influencia da doutrina comparatista. In: $O$ direito civil no seculo XXI. Coord. Maria Helena Diniz e Roberto Sentse Lisboa. Säo Paulo: Saraiva, $2003_{s}$ p. 547.

7 HESSE, Konrad. Escritos de dercho constitucional. Trad. Pedro Cruz Villalon. Madrid: Centro de Estudos Constitucionais, 1992, p. 50.

77. BONAVIDES, Paulo. Curso de direito constitucional. São Paulo: Matheiros, 1998, p. 477. 
operação mais complexa e minuciosa a que o jurista pode dedicar-se, reclamando sensibilidade ímpar, apurado senso, intuição feliz, experiência vasta e adequado domínio não só do direito positivo, mas especialmente da alma de determinado sistema jurídico. ${ }^{73}$

O exercício de exegese pressupõe hodiernamente, não apenas a aplicação dos frios textos legais, mas a atividade tópica inspirada na atual roupagem do direito civil neste início de século XXI.

Neste condão pode ser afirmado então que ao juiz não é dada a tarefa de aplicar regras rígidas e engessadas nos códigos ao caso concreto, mas sim é atribuído o dever de, à luz da principiologia constitucional, distribuir justiça.

Demonstrada a importância da hermenêutica jurídica, ciência do direito que se incumbe do estudo sistemático da interpretação, há de salientarse que tantos os textos de lei como os negócios jurídicos (= lei entre particulares), merecem adequada exegese, posto que, por mais hialina que seja sua construção gramatical, o simples enunciado não permite que se enxergue sua aura nem seus fins. Ato contínuo, tem-se por certo que todas as normas são suscetíveis de interpretação, ante seu significado intrínseco. ${ }^{74}$

Dentre os vários métodos de interpretação, o hermeneuta deverá optar por aquele, ou aqueles, que mais se afeiçoem do objeto do estudo, podendo amparar-se no método literal, no lógico, no sistemático, no histórico ou ainda no teleológico ou finalístico.

O que não se pode deixar de lado é que o direito é uno e dentro de um sistema legislativo, há de respeitar-se a coerência do complexo jurídico. Assim, a idéia de sistema está umbilicalmente ligada a de ordem, sendo este uma totalidade ordenada, entes que se relacionam com o todo e também ao mesmo tempo entre si, numa simbiose de coerência, sendo de fundamental importância para a distribuição de justiça no seio social. ${ }^{75}$

De fato, uma norma, ou o negócio jurídico, se analisados de modo singular e isolado, podem assumir valor e destaque inesperados, caso sejam interpretados sem a presença do elemento sistemático integrador. ${ }^{76}$

\footnotetext{
7. FERRARA, Francesco. Interpretação e aplicação das leis. Trad. Manuel A Domingues de Andrade. Coimbra: Armentio Amado, 1978, p. 129.

${ }^{74}$ BITTAR, Carlos Alberto. O direito civil na constituição de 1988. Săo Paulo: RT, 1991, p. 31

${ }_{75}$ BOBBIO, Norberto. Teoria do ordenamento jurídico. Trad. Maria Celeste Cordeiro Leite dos Santos. Brasilia: Editora UNB, 1999 , p. 71-114.

7" FERRARA, Francesco. Interpretaçäo e aplicação das leis. Trad. Manuel A. Domingues de Andrade. Coimbra: Armenio Amado, 1978, p. 143.
} 
Neste contexto, resta evidente, que a interpretação dos negócios jurídicos não pode fugir a essência do texto constitucional, sendo que qualquer raciocínio neste sentido certamente estará viciado perpetuamente, merecendo uma alva lápide a relatar-lhe a morte.

Outrossim, a norma constitucional também influenciou a produção legislativa, eis que no Brasil está às vésperas de debutar. Diversas normas foram editadas sob o pálio da Constituição Federal de 1988, atribuindose especial enfoque aos textos do Código de Defesa do Consumidor e do Código Civil.

Quanto a este último, muito se comenta sobre supostas inovações, sendo que em verdade, não se pode notar a quebra de qualquer paradigma ante a posição já assentada na doutrina e jurisprudência pátria, fato que em momento algum retira seu brilho e importância.

\subsection{A função social do contrato}

Fruto da influencia citada e transplantada do texto constitucional para o direito civil, a função social do contrato há de ser elevada à condição de requisito ${ }^{77}$ do negócio jurídico; e o titular de tal direito subjetivo seria o individuo ou o grupo de pessoas que sofreu a ofensa.

Talvez, ao menos possa afirmar-se que, a coletividade ofendida poderá amparar-se-ia na idéia do abuso de direito, que estabelece limites contra "atitudes egoístas e anti-sociais do titular do direito" ", para tornar-se indene dos prejuizos que the sejam causados pela inobservância da função social.

Pela nulidade entende Paulo Nalin ${ }^{79}$, vez que a inobservância do princípio em comento ofende de forma direto o texto constitucional. Evai além, ao qualificála como virtual, na medida em que não existe sançäo expressa do ordenamento jurídico. No mesmo sentido leciona Roberto Senise Lisboa ${ }^{80}$ para quem qualquer obrigação contraída em sacrificio dos valores sociais seria nula.

\footnotetext{
"Entendemos que conforme a situação, a ausência de observância à função social do contrato, poderá ser tratada no plano da walidade ou da eficácia, posto que năo há sanção especiftca no atual modelo legislativo. Deste modo um contrato que

$7 *$ LOUREIRO, Luiz Guilherme. Teoria geral dos contratos no novo código civil. São Paulo: Método, 2002, p. 81

7 NAIN, Paulo. Do contrato: concẹto pós-moderno em busca de sua formulação na perspectiva crivilconstitucional. Curitiba: Juruá, 2001, p. 236-242.

LISBOA, Roberto Senise. Contratos difusos e coletivos: consumidor, meio ambiente, trabalho, tocação, autot. São Paulo: KT, 2000, p. 72.

* WALD, Arnoldo. Um novo dircito para a nova economia: a evoluçăo dos contratos e o código civil. In: O direito ciril no século XXI. Coord. Maria Helena Diniz e Roberto Senise Lisboa. São Paulo: Saraiva, 2003 , p. 89.
} 
Mas será que realmente não há sanção expressa no sistema para as hipóteses de inobservância dos princípios ? Não seria o princípio da função social (bem como a boa-fé e a probidade dentre outros) uma norma de natureza cogente, fruto da publicização do direito privado, quando inseridos nos ordenamentos infraconstitucionais?

Deste modo, há de ser destacado o teor do inciso VII do artigo 166 do Código civil ao dispor que o negócio jurídico será nulo quando "a lei taxativamente o declarar nulo, ou proibir-lhe a prática, sem impor sanção".

Nesta linha de raciocínio, não estaria a lei, ao impor que o princípio deverá ser observado, está a proibir-lhe a inobservância, e por consequiência autorizaria a aplicação do dispositivo legal citado (??); muito embora se saiba que a classificação trinaria do conteúdo deôntico da norma seja classificado em normas de caráter permissivo, proibitivo e obrigatório, e dentro do necessário rigor formal, os princípios, tal qual restam positivados no atual Código Civil, aproximem-se mais da última classificação.

A gênese do princípio hoje aplicável ao direito negocial encontra-se na função social da propriedade positivada pelo legislador constitucional. Ocorre que à palavra propriedade há de ser dado amplo entendimento, sendo que o mesmo princípio, seja por interpretação extensiva ou por analogia, haveria de ser aplicado aos títulos de crédito e por conseqüência às obrigações em geral; o que não quer dizer que o contrato também não tenha sua função individual, sob pena de, em se ignorando tal premissa, implodir-se o contrato ${ }^{81}$, espécie mais importante de negócio jurídico.

Ato contínuo, não se pode esquecer que pelos contratos, as partes devem buscar o consenso evitando a opressão, pois hão de ser pactuados com o necessário espírito de fraternidade. ${ }^{82}$

Uma das funções do princípio em comento, seria a de velar pela distribuição de riquezas de modo eqüitativo, evitando-se o enriquecimento sem causa, permitido-se o progresso social; posto que toda vez que a operação econômica revestida pelo contrato ofender a valores como a dignidade da pessoa humana, os valores sociais do trabalho e da livre iniciativa; a equidade e a solidariedade, certamente a função social do contrato não terá sido observada. ${ }^{83}$

Outrossim, indaga-se se o interesse de terceiros também deverão ser respeitados, posto que o novo codex de direito privado é inspirado pelo prinćpio da solidariedade, sob o pálio da igualdade material preconizada pelo texto constitucional?

${ }^{2}$ AZEVEDO, Álvaro Villaça. Teoria gexal dos contratos típicos e atípicos. São Paulo: Atlas, 2002, p. 28. : LOURERO, Luiz Guilherme. Teoria geral dos contratos no nowo codigo civil. São Paulo Metodo, 2002, p. 52. 
Nesta esteira de pensamento Mônica Bierwagen ${ }^{84}$ leciona que, há contratos que, muito embora sirvam aos desejos dos contratantes, não se mostram adequados ao interesse social, como na hipótese da área que é locada por uma empresa para armazenamento de lixo tóxico sem o necessário tratamento, ou na situação em que se realiza a distribuição de amostras grátis de bebida alcoólica em frente a um posto dos Alcoólatras Anônimos. Nesses casos, certamente há ofensa a direitos sociais, seja no primeiro caso o direito a um meio ambiente limpo e no segundo o tratamento do alcoólatra, o que não pode ser ignorado em favor da autonomia da vontade.

Dos exemplos citados, salvo melhor juizo, parece que a ofensa na primeira hipótese, seria muito grave no que pertine à questão ambiental do que na seara do direito privado, invocando-se então o Art. 225 da Carta Magna, não sendo necessária a aplicação do princípio da função social, ante a especificidade de princípios que regam o tema.

Por outro lado, questiona-se se os indivíduos lesados teriam a titularidade do direito subjetivo para impedir o funcionamento da empresa de bebida (!?); parecendo que não.

Crê-se que a solução mais racional para o caso divida-se em dois mecanismos, sendo o primeiro de índole processual, por meio da ação civil pública e o segundo, de ordem política-administrativa, por meio da atuação do Poder Público ao restringir tais atividades, o que pode ser feito por normas de zoneamento urbano.

Em que pese a sustentabilidade do argumento desenvolvido, há de destacarse por outro lado que tal possibilidade de controle externo da vontade negocial desvirtuaria a autonomia privada, deixando a mesma de servir de instrumento para o desenvolvimento da personalidade, transformando-a em mera função ou finalidade. ${ }^{85}$ Uma hipótese a ser pensada justifica o raciocínio.

Imaginem a possível fusão de duas empresas (situação bastante freqüente), por meio de um negócio jurídico, sem cuja existência e eficácia levará ambas à falência. Reflexo direto da fusão (ou incorporação) será a dispensa de parte do quadro de funcionários, muitos deles com idade avançada.

Teriam os membros da "lista negra" direito à indenização apenas sob o argumento de que o mercado é discriminatório e não mais conseguirão empregos ? Seria possível advogar a tese que lhes é devida indenização por danos extrapatrimoniais, sob o argumento de que, após algum

\footnotetext{
BHERWAGEN, Mônica Yoshizato. Princípios e regras de interpretação cos comuatos no novo código civil. Säo Paulo: Saraiya, 2002, p. 44-45.

: VON GEHLEN, Gabriel Menna Barreto. $O$ chatnado direito civil constitucional. In: A reconstruçăo do direito privado. Org. Judith Martins Costa. Säo Paulo: RT, 2002, p. 196.
} 
tempo de procuram não conseguiram retornar ao mercado de trabalho (discriminatório por natureza) ante a larga experiência de vida ? Haverá direito a indenização se o novo emprego the remunerar em padrōes bastante inferiores se comparados ao antigo salário e por conseqüência o nível de vida teve que ser alterado?

Sinceramente parece que não, posto que são vários os interesses $\mathrm{em}$ jogo, entre eles os que pertencem aos antigos colegas de trabalho, também destinatários do princípio em comento, e porque não da sociedade como um todo, posto que dos bens produzidos pela empresa, um cota será apreendida pelo Estado por meio da atividade tributária.

\section{Conclusão}

A partir do momento em que a palavra escrita passou a ser difundida, a humanidade teve facilitado seu acesso ao conhecimento, e isto muito antes de seres desenvolvidos os recursos de multimídia hodiernamente difundidos no seio da sociedade. Grande parte do conhecimento, que hoje pertence aos homens, foi transmitido por meio dos papiros da antiguidade e dos livros escritos e copiados nos monastérios da Idade Média. Em homenagem à palavra escrita, durante longa data proibida de ser transcrita no papel, seu principal parceiro, conclui-se, após este modesto estudo, que:

1. O mito das codificações encontra-se definitivamente sepultado ante a ingerência dos princípios constitucionais.

2. O Direito privado não é auto-suficiente, e as diretrizes da Carta Magna devem ser utilizadas na exegese de qualquer dos seus dispositivos.

3. A autonomia privada sofreu ao longo do século passado enorme restrição a ponto de dela, ter brotado, um novo princípio sob a denominação de princípio da heteronomia da vontade.

4. A constitucionalização do direito significa a atração para a órbita constitucional de materias que interessam aos particulares e publicização do direito quer dizer a intervenção estatal, por meio de normas infraconstitucionais de natureza cogente.

5. A constitucionalização do direito civil é fruto da interpretação sistemática, vez que, o ordenamento, possui como um de seus elementos a coerência, e por conseqüência há de se respeitar às diretrizes que emanam do topo da pirâmide hierárquica.

6. O hipossuficiente é tutelado ante a necessária busca pela justiça material, sob inspiração do princípio constitucional da economia. 
7. O texto do novo Código Civil é informado por alguns princípios de suma importância, entre eles a sociabilidade, a eticidade e a operabilidade, filhos dos princípios constitucionais da dignidade da pessoa humana e da isonomia.

8. A norma constitucional influencia o negócio jurídico na medida em que deve ser suscitada em todas as hipóteses de exegese, mas também na medida em que, enquanto lastro de todo o sistema, motiva alteraçoes legislativas na busca do bem comum.

9. Aferiu-se ainda que valores como a boa-fé e a função social devem sempre estar presentes nos momentos de formação e execução do negócio jurídico, sob pena do mesmo ser taxado como virtualmente nulo, em razão da ausência expressa de sanção.

10. A principal razão da morte do contrato em sua concepção clássica, se dá ante a premente necessidade de se alcançar o bem comum e a justiça comutativa, mediante a redução das desigualdades sociais que se espalham pelo planeta Terra.

11. E há de destacar-se ainda que, existe a possibilidade da tutela do interesse de terceiros que venham a ser lesados indiretamente por negócios jurídicos, situação que há de ser analisada com a devida parcimônia, eis que o risco da ingerência da vontade alheio nos negócios jurídico põe em cheque a segurança esperada.

\section{BIBLIOGRAFIA}

ALBUQUERQUE, Ronaldo Gatti de. Constituição de codificação: a dinâmi$\mathrm{ca}$ atual do binômio. In: A reconstrução do direito privado. Org. Judith Martins Costa. São Paulo: RT, 2002.

AMARAL, Francisco. Direito civil: introdução. Rio de Janeiro: Renovar, 2002. Autonomia privada. In: Comentários sobre o projeto de código civil brasileiro. Brasília: CJF, 2002.

AZEVEDO. Alvaro Villaça. Teonia geral dos contratos típicos e atípicos. São Paulo: Atlas, 2002. BETTI, Emílio. Teoria geral dos negócios jurídicos. Coimbra: Ed. Coimbra, 1969, tomo I. BIERWAGEN, Mônica Yoshizato. Princípios e regras de interpretação dos contratos no novo código civil. São Paulo: Saraiva, 2002.

BITTAR,Carlos Alberto. O direito civil na constituição de 1988. São Paulo: RT, 1991. BOBBIO, Norberto. Teoria do ordenamento jurídico. Trad. Maria Celeste Cordeiro Leite dos Santos. Brasília: Editora UNB, 1999.

BONAVIDES, Paulo. Curso de direito constitucional. São Paulo: Malheiros, 1998. BORGES, Nelson. A tcoria da imprevisão no direito civil e no processo civil. São Paulo: Malheiros, 2002.

BRAVO, Maria Celina; SOUZA, Mário Jorge Uchoa. O contrato do terceiro 
milênio. Artigo capturado na internet: http://www1.jus.com.br/doutrina/ texto.asp?id=2365, em 15.06.2002.

COELHO, Luiz Femando. Teoria critica do direito. Belo Horizonte: Del Rey, 2003. CORDEIRO, Antônio Menezes. Tratado de direito civil português: parte geral. Almedina: Lisboa, 2000, tomo I.

COSTA, Judith Martins. Boa-fé no direito privado. São Paulo: RT, 2000.

DONNINI, Rogério Ferraz. A Constituição Federal e a concepção social do contrato. In: Temas atuais de direito civil na Constituição Federal. Organização: Rui Geraldo Camargo Viana e Rosa Maria de Andrade Nery. São Paulo: Revista dos Tribunais, 2000.

ESPINOLA, Eduardo. Dos contratos nominados no direito civil brasileiro. Atualização: Ricardo Rodrigues Gama. Campinas: Bookseller, 2002.

FACHIN, Luiz Edson. Novo conceito de ato e negócio jurídico: conseqüências práticas. Curitiba: EDUCA, SCIENTIA et LABOR, 1988.

Teoria crítica do direito civil. Rio de Janeiro: Renovar, 2000.

FERRARA, Francesco. Interpretação e aplicação das leis. Trad. Manuel A. Domingues de Andrade. Coimbra: Armênio Amado, 1978.

FERREIRA Jussara Suzi Assis Borges Nasser. Bioética e biodireito: a superação da lei. Palestra proferida no VI Semana Jurídica de Paranavaí. Paranavaí, 27 de agosto de 2001. FILOMENO, José Geraldo Brito. Código de defesa do consumidor comentado pelos autores do anteprojeto. Ada Pellegrini Grinover [et al.]. Rio de Janeiro: Forense Universitária, 1997.

FRADERA, Véra Maria Jacob de. O direito dos contratos no século XXI: a construção e uma noção metanacional de contrato decorrente da globalização, da integração regional e sob influencia da doutrina comparatista. In: $O$ direito civil no século XXI. Coord. Maria Helena Diniz e Roberto Senise Lisboa. São Paulo: Saraiva, 2003.

GRAU, Eros Roberto. Ensaio e discurso sobre a interpretação / aplicação do direito, São Paulo: Malheiros, 2002.

HESSE, Konrad. Escritos de derecho constitucional. Trad. Pedro Cruz Villalon. Madrid: Centro de Estudos Constitucionais, 1992.

KÜMPEL, Vitor Frederico. Direito civil: apontamentos sobre o novo código civil: Lei 10.406/02. Módulo complementar desenvolvido no Congresso Nacional de Direito Civil. Curitiba, 2003.

LISBOA, Roberto Senise. Contratos difusos e coletivos: consumidor, meio ambiente, trabalho, locação, autor. São Paulo: RT, 2000.

LOBO, Paulo Luiz Netto. Direito contratual c constituição. Artigo capturado na internet: http:/wwwl.jus.com.br/doutrina/texto.asp?id-563, em 13.05.2002. Artigo capturado na internet: Constitucionalização do direito civil. www.mundojuridico.adv.br, em 05.07.2003.

LORENZETTI, Ricardo Luis. Fundamentos do direito privado. Trad. Vera Maria Jacob de Fradera. São Paulo: RT, 1998.

LOUREIRO, Luiz Guilherme. Teoria geral dos contratos no novo código civil. São Paulo: Método, 2002. 
LOURENÇO, José. O dirigismo contratual, a publicização do direito privado pela intervenção do estado e a heteronomia da vontade como princípio do contrato. In: $O$ direito civil no século XXI. Coord. Maria Helena Diniz e Roberto Senise Lisboa. São Paulo: Saraiva, 2003.

MARTINS COSTA, Judith; BRANCO, Gerson Luiz Carlos. Diretrizes teóricas do novo código civil brasileiro. São Paulo: Saraiva, 2002.

MOTA PINTO. Carlos Alberto da. Teoria geral do direito civil. Coimbra: Coimbra Editora, 1992.

NALIN, Paulo. Do contrato: conceito pós-moderno em busca de sua formulação na perspectiva civil-constitucional. Curitiba: Juruá, 2001.

NERY JUNIOR, Nelson. O novo Código Civil e sua influência no Direito Brasileiro e no Processo Civil. Palestra proferida no II Congresso Paranaense de Processo Civil. Curitiba, 09-11 de maio de 2002.

NOVAIS, Alinne Arquette Leite. A teoria contratual e o código de defesa do consumidor. São Paulo: RT, 2001.

PEREIRA, Caio Mário da Silva. Instituições de direito civil. vol. III. Rio de Janeiro: Forense, 2001.

- Lesão nos contratos. Rio de Janeiro: Forense, 2001.

PEREZ, Jesus Gonzales. La dignidade de la persona. Cidade Desconhecida: Civitas S.A, 1968.

REALE, Miguel. As diretrizes fundamentais do projeto do código civil. In: Comentários sobre o projeto de código civil brasileiro. Brasília: CIF, 2002. RIPERT, Georges. A regra moral nas obrigações civis. Trad. Osório de Oliveira. Campinas: Bookseller, 2002.

RIZZARDO, Arnaldo. Contratos. Rio de Janeiro: Forense, 2001.

GAGLIANO, Pablo Stolze; PAMPLONA FILHO, Rodolfo. Novo curso de direito civil: parte geral. São Paulo: Saraiva, 2002.

SANTOS, Antônio Jeová. Função social, lesão e onerosidade excessiva nos contratos. São Paulo: Método, 2003.

TEPEDINO, Gustavo. O código civil, os chamados microssistemas e a Constituição: premissas para uma reforma legislativa. In: Problemas de direito civil constitucional. Coord. Gustavo Tepedino. Rio de Janeiro: Renovar, 2001.

VERISSTMO, Luis Fernando. Banquete com os deuses: cinema, literatura, música e outras artes. Rio de Janeiro: Objetiva, 2003.

VON GEHLEN, Gabriel Menna Barreto. O chamado direito civil constitucional. In: A reconstrução do direito privado. Org. Judith Martins Costa. São Paulo: RT, 2002.

WALD, Annoldo. Um novo direito para a nova economia: a evolução dos contratos e o código civil. In: O direito civil no século XXI. Coord. Maria Helena Diniz e Roberto Senise Lisboa. São Paulo: Saraiva, 2003. 